\title{
PSYCHOANALYSIS AND ZEN BUDDHISM
}

\author{
ERICH FROMM
}

National University of Mexico \& Michigan State University

In relating Zen Buddhism to psychoanalysis, one discusses two systems, both dealing with a theory concerned with the nature of man and with a practice leading to his wellbeing. Each is a characteristic expressions of Eastern and Western thought, respectively. Zen Buddhism is a blending of Indian rationality and abstraction with Chinese concreteness and realism. Psychoanalysis is as exquisitely Western as Zen is Eastern; it is the child of Western humanism and rationalism, and of the XIX Century romantic search for the dark forces which elude rationalism. Much further back, Greek wisdom and Hebrew ethics are the spiritual godfathers of this scientific-therapeutic approach to man.

But in spite of the fact that both psychoanalysis and Zen deal with the nature of man and with a practice leading to his transformation, the differences seem to outweigh these similarities. Psychoanalysis is a scientific method, non-religious to its core. Zen is a theory and technique to achieve "enlightenment", an experience which in the West would be called religious or mystical. Psychoanalysis is a therapy for mental illness; Zen a way to spiritual salvation. Can the discussion of the relationship between psychoanalysis and Zen Buddhism result in anything but the statement that there exists no relationship except that of radical and unbridgeable difference?

Yet there is an unmistakable and increasing interest in Zen Buddhism among Western psychoanalysts. ${ }^{1)}$ What are the sources of this interest, what is its meaning? To give an answer to this question is what this paper attempts to do. It does not try to give a systematic presentation of Zen Buddhist thought, a task which would transcend my knowledge and experience; neither does it try to give a systematic presentation of psychoanalysis, which would be beyond the scope of this paper. Rather, I shall try to show why the study of Zen Buddhism has been of vital significance to me and, as I believe-is significant for all students of psychoanalysis. But even though this paper does not contain a complete and systematic outline, and hence no systematic comparison between psychoanalysis and Zen, I shall try to discuss those elements in psychoanalysis and in Zen which seem to have a profound affinity with each other, as well as those aspects in which the two systems are different.

* Editor This contribution is a part of Dr. Fromm's paper which will be published with the papers of Dr. Suzuki and Mr. DeMartino.

1) cf. Jung's introduction to D.T. Suzuki's “Zen Buddhisı", Rider, London, 1949; the French psychiatrist, Benoit's work on Zen Buddhism, "The Supreme Doctrine", Pantheon Books, New York, 1955; the late Karen Horney was intensely interested in Zen Buddhism during the last years of her life; and the conference held in Cuernavaca, Mexico, at which the papers to be published in the forthcoming book, D.T. Suzuki, Erich Fromm, and Richard DeMartino "Psychoanalysis and Zen Buddhism", Harper, New York, were presented, is another symptom of the interest of psychoanalysts in Zen Buddhism. There is also considerable interest in Japan in the relation between psychotherapy and Zen Buddhism.

cf. Koji Sato's paper on Psychotherapeutic Implications of Zen, in Psychologia, An International Journal of Psychology in the Orient, Vol.I, No.4, 1958, and other papers in the same issue. 
I.

As a first approach to our topic, I must consider the spiritual crisis which Western man is undergoing in this crucial historical epoch, and the function of psychoanalysis in this crisis.

While the majority of people living in the West do not consciously feel as if they were living through a crisis of Western culture (probably never have the majority of people in a radically critical situation been aware of the crisis), there is agreement, at least among a number of critical observers, as to the existence and the nature of this crisis. It is the crisis which has been described as "malaise", "ennuie", "mal du siecle", the deadening of life, the automatization of man, his alienation from himself, from his fellow-man and from nature." Man has followed rationalism to the point where rationalism has transformed itself into utter irrationality. Since Descartes, man has increasingly split thought from affect; thought alone is considered rational-affect, by its very nature, irrational; the person, $I$ was split off into an intellect, which constitutes myself, and which is to control me as it is to control nature. Control by the intellect over nature, and the production of more and more things, became the paramount aim of life. In this process man has transformed himself into a thing, life has become subordinated to property, "to be "is dominated by "to have". Where the roots of Western culture, both Greek and Hebrew, considered as the aim of life the perfection of man, modern man is concerned with the perfection of things, and the knowledge of how to make them. Western man is in a state of schizoid inability to experience affect, hence he is anxious, depressed and desperate. He still pays lip service to the aims of happiness, individualism, initiative-but actually he has no aim. Ask him what he is living for, what the aim of all his strivings is-and he will be embarrassed. Some may say they live for the family, others "to have fun", still others to make money, but in reality nobody knows what he is living for; he has no goal, except the wish to escape insecurity and aloneness.

It is true, church membership today is higher than ever before, books on religion become best-sellers, and more people speak of God than ever before. Yet this kind of relgious pro- fession only covers up a profoundly materialistic and irreligious attitude, and is to be understood as a conscious reaction-caused by insecurity and conformism-to the trend of the nineteenth century, which Nietzsche characterized by his famous "God is dead". As a truly religious attitude, it has no reality.

The abandonment of theistic ideas in the nineteenth century was-seen from one angle - no small achievement. Man took a big plunge into objectivity. The earth ceased to be the center of the universe; man lost his central role of the creature destined by God to dominate all other creatures. In this process of giving up illusions, man recognized the concept of God as an illusion; he saw that this concept had its root in the very helplessness of human existence and in man's attempt to cope with his fright, by the belief in a helping father or mother represented by a God in heaven. He saw that man only can save himself; the teaching of the great teachers, the loving help of parents, friends and loved ones can help him but help him only to dare to accept the challenge of existence and to react to it with all his. might and all his heart.

1) cf. the writings of Kierkegard, Marx, Nietzsche and, at present, of existentialist philosophers and Lewis Mumford, Paul Tillich, Erich Kahler, and others. 
Man gave up the illusion of a fatherly God, as a parental helper-but he gave up also the true aim of all great humanistic religions; that of overcoming the limitations of an egotistical self, that of achieving love, objectivity and humility, of respecting life and of considering the aim of life living itself, for man to bccome what he potentially is. These were the ainus of the great Western religions, as they were the aims of the great Eastern religions. The East, however, was not burdened with the God concept of a transcendent father-savior in which the monotheistic religions expressed their longings. Taoism and Buddhism had a rationality and realism superior to the Western religions. They could see man realistically and objectively, having nobody but the "awakened" ones to guide hin, and being able to be guided because each man has within himself the capacity to awake and be enlightened. This is precisely the reason why Eastern religious thought, Taoism and Buddhism-and their blending in Zen Buddhism-assume such importance for the West today. Zen Buddhism helps man to find an answer to the question of his existence, an answer which is essentially the same as that given in the Judaeo-Christian tradition, and yet it does not contradict the rationality, realism and independence which are modern man's precious achievements. Paradoxically, Eastern religious thought turns out to be more congenial to Western rational thought than Western religious thought itself.

II.

The essence of Zen is the acquisition of enlightenment (satori). Without having had this experience, $Z$ en is never fully understood. Since I have not experienced satori, I can talk about Zen only in a tangential way, and not as it ought to be talked about-out of the fullness of experience. But this is not as C. G. Jung has suggested because satori "depicts an art and a way of enlightenment which is practically impossible for the European to appreciate". 1) As far as this goes, Zen is not more difficult for the European than Heraclitus, Master Eckhart, or Heidegger. The difficulty lies in the tremendous effort which is required to acquire satori; this effort is more than most people are willing to undertake, and that is why satori is rare even in Japan. Nevertheless, even though I cannot talk of Zen with any authority, the good fortune of having read Dr. Suzuki's books, heard quite a few of his lectures, and read whatever else was available to me on Zen Buddhism, has given me at least an approximate idea of what constitutes $Z$ en, and idea which I hope enables me to make a tentative comparison between Zen Buddhism and psychoanalysis.

What is the basic aim of Zen?

To put it in Suzuki's words: "Zen in its essence is the art of seeing into the nature of one's being and it points the way from bondage to freedom.... We can say that Zen liberates all the energies properly and naturally stored in each of us, which are in ordinary circumstances cramped and distorted so that they find no channel for activity.... It is the object of Zen, therefore, to save us from going crazy or being crippled. This is what I mean by freedom, giving free play to all the creative and benevolent impulses inherently lying in our hearts. Gencrally, we are blind to this fact, that we are in possession of all the necessary faculties that will nake us happy and loving towards one another."2) We find in this definition a number

1) D.T. Suzuki, "Introduction to Zen Buddhism", Rider, London, 1949, p. 9/10. (Foreword by C.G. Jung).

2) D.T. Suzuki, "Zen Buddhism", Doubleday Anchor Books, New York, 1956, p. 3. 
of essential aspects of Zen which I should like to emphasize; Zen is the art of seeing into the nature of one's being; it is a way from bondage to freedom; it liberates our natural chergies; it prevents us from going crazy or being crippled; and it impels us to express our faculty for happiness and love.

The final aim of Zen is the experience of enlightenment, called satori. Dr. Suzuki has given, in these lectures, and in his other writings, as much of a description as can be given at all. In these remarks I would just like to stress some aspects which are of special importance for the Western reader, and especially for the psychologist. Satori is not an abnormal state of mind; it is not a trance in which reality disappears. It is not a narcisistic state of mind, as can be seen in some religious manifestations. "If anything, it is a perfectly normal state of mind ..." As Joshu declared, "Zen is your everyday thought", it all depends on the adjustment of the hinge, whether the door opens in or opens out." 1) Satori has a peculiar effect on the person who experiences it. "All our mental activities will now be working on a different key, which will be more satisfying, more peaceful, more full of joy than anything you ever experienced before. The tone of life will be altered. There is something rejuvenating in the possession of Zen. The spring fower will look prettier, and the mountain stream runs cooler and more transparent." 2 )

It is quite clear that satori is the true fulfillment of the state of well-being which Dr. Suzuki described in the passage quoted above. If we would try to express enlightenment in psychological terms, I would say that it is a state in which the person is completely tuned to the reality outside and inside of him; that he is fully aware of it and fully grasps it. He is aware of it-that is, not his brain, nor any other part of his organism, but he, the whole man. He aware of $i t$; not as of an object overthere which he grasps with his thought, but it, the flower, the dog, the man, in its or his full reality. He who awakes is open and responsive to the world, and he can be open and responsive because he has given up holding on to hinself as a thing, and thus has become empty and ready to receive. To be enlightened means "the full awakeness of the total personality to reality."

It is very important to understand that the state of enlightenment is not a state of dissociation or of a trance in which one believes oneself to be awakened, when one is actually deeply asleep. The Western psychologist, of course, will be prone to believe that satori is just a subjective state, an auto-induced sort of trance, and even a psychologist as sympathetic to Zen as Dr. Jung cannot avoid the same error. Jung writes: "The imagination itself is a psychic occurrence, and therefore, whether an enlightenment is called real or imaginary is quite immaterial. The man who has enlightenment, or alleges that he has it, thinks in any case that he is enlightened... Even if he were to lie, his lie would be a spiritual fact." ${ }^{3}$ ) This is, of course, part of Jung's general relativistic position with regard to the "truth" of religious experience. Contrary to him, I believe that a lie is never "a spiritual fact", nor any other fact for that matter, except that of being a lie. But whatever the merits of the case, Jung's position is certainly not shared by Zen Buddhists. On the contrary, it is of crucial

1) D.T. Suzuki, "Introduction to Zen Buddhism", Rider, London, 1949, p. 97.

2) Ibid. p. $97 / 98$.

3) D.T. Suzuki, 1, c. p. 15. 
importance for them to differentiate between genuine satori experience, in which the acquisition of a new view-point is real, and hence true, and a pseudo-experience which can be of a hysterical or psychotic nature, in which the Zen student is convinced of having obtained satori, while the Zen master has to make it clear that he has not. It is exactly one of the functions of the Zen master to watch and to prevent confusion between real and imaginary enlightenment.

The full awakeness to reality means, again speaking in psychological terms, to have attained a fully "productive orientation". That means not to relate oneself to the world receptively, exploitatively, hoardingly, or in the marketing fashion, but creatively, actively (in Spinoza's sense). In the state of full productiveness there are no veils which separate me from the "not me". The object is not an object any more; it does not stand against me, but is with me. The rose I see is not an object for my thought, in the manner that when I say "I see a rose" I only state that the object, a rose, falls under the category "rose", but "a rose is a rose is a rose". The state of productiveness is at the same time the state of highest objectivity; I see the object without distortions by my greed and fear. I see it as it or he is, not as I wish it or him to be or not to be. In this mode of perception there are no parataxic distortions. There is complete aliveness, and the synthesis is of subjectivity - objectivity. I experience intensely - yet the object is left to be what it is. I bring it to life - and it brings me to life. Satori appears mysterious only to the person who is not aware of the fact to what degree his perception of the world is purely mental, or parataxical. If one is aware of this, one is also aware of a different awareness, that which one can also call a fully realistic one. One may have only experienced glimpses of it - yet one can imagine what it is. A little boy studying the piano does not play like a great master. Yet the master's playing is nothing mysterious; it is only the perfection of the rudimentary experience the boy has. That the undistorted and non-cerebral perception of reality is an essential element of Zen experience is expressed quite clearly in two Zen stories. One is the story of a master's conversation with a monk:

"Do you ever make an effort to get disciplined in the truth?"

"Yes, I do."

"How do you exercise yourself :"

"When I am hungry, I eat; when I am tired, I sleep."

"This is what everybody does; can they be said to be exercising themselves in the same way as you do?"

"No."

"Why not?"

"Because when they eat, they do not eat, but are thinking of various other things, thereby allowing themselves to be disturbed; when they sleep, they do not sleep, but dream of a thousand and one things. This is why they are not like myself." 1)

The story hardly needs any explanation. The average person, driven by insecurity, greed, fear, is constantly enmeshed in a world of phantasies (not necessarily being aware of it) in which he clothes the world in qualities which he projects into it, but which are not there. This was true at the period when this conversation took place; how much more drastically

1) D.T. Suzuki, op. cit. p. 86. 
is it true today, when almost everybody sees, hears, feels, and tastes with his thoughts, rather than with those powers within himself which can see, hear, feel and taste.

The other, equally revealing statement, is that of a Zen master who said: "before I was enlightened the rivers were rivers and the mountains were mountains. When I began to be enlightened the rivers were not rivers any more and the mountains were not mountains. Now, since I am enlightened, the rivers are rivers again and the mountains are mountains." Again we see here the new approach to reality. The average person is like the man in Plato's cave, sceing only the shadows and mistaking then for the substance. Once he has recognized this error, he only knows that the shadows are not the substance. Once he is enlightened, he has left the cave and its darkness for the light: there he sees the substance and not the shadows. $\mathrm{He}$ is awake. As long as he is in the dark, he cannot understand the light (as the Bible says: "A light shines in the darkness and the darkness understandeth not.") Once he be out of the darkness, he understands the difference between how he saw the world as shadows and how he sees it now, as real.

Zen is aimed at the knowledge of one's own nature. It searches for the "know thyself". But this knowledge is not the "scientific" knowledge of the modern psychologist, the knowledge of the knower-intellect who 'knows the object-himself as object, torn away; knowledge of self in Zen is knowledge which is not intellectual, non alienated, but full experience in which knower and known become one. As Suzuki has put it: "The basic idea of Zen is to come in touch with the inner workings of one's being, and to do this in the most direct way possible, without resorting to anything external or superadded." 1)

This insight into one's own nature is not an intellectual one - standing outside, but an experiential one, being inside, as it were. This difference between intellectual and experiential knowledge is of central importance for Zen and, at the same time, constitutes one of the basic difficulties the Western student has in trying to understand Zen. The West, for two thousand years (and with only few exceptions, such as the mystics) has believed that a final answer to the problem of existence can be given in thought; the "right answer" is religion and in philosophy was of paramount importance. By this insistence, the way was prepared for the flourishing of the natural science. Here the right thought, while not giving a final answer to the problem of existence, is inherent in the methed and necessary for the application of the thought to practice, that is, for technique. Zen, on the other hand, is based on the premise that the ultimate answer to life can not be given in thought. "The intellectual groove of 'yes' and 'no' is quite acconmodating when things run their regular course; but as soon as the ultimate question of life comes up, the intellect fails to answer satisfactorily." 2) For this very reason, the experience of satori can never be conveyed intellectunlly. It is "an experience which no amount of explanation and argument can make communicable to others, unless the latter themselves had it previously. If satori is amenable to analysis in the sense that by so doing it becomes perfectly clear to another who has never had it, that satori will not be satori. For a satori turned into a concept ceases to be itself; and there will no more be a Zen experience." 3)

1) D.T. Suzuki, op. cit. p. 44.

2) D.T. Suzuki, op. cit. p. 67.

3) D.T. Suzuki, op. cit. p. 92. 
It is not only that the final answer to life can not be given by any intellectual formulation; in order to arrive at enlightenment, one has to do away with the many constructs of the mind, which impede true insight. "Zen wants one's mind free and unobstructed; even the idea of oneness and allness is a stumbling block and a strangling snare which threatens the original freedom of the spirit." 1) As a further consequence, the concept of participation or empathy, so emphasized by Western psychologists is unacceptable to Zen thought. "The idea of participation or empathy is an intellectual interpretation of primary experience, while as far as the experience itself is concerned, there is no room for any sort of dichotomy. The intellect, however, obtrudes itself and breaks up the experience in order to make it amenable to intellectual treatment, which means a discrimination or bifurcation. The original feeling of identity is then lost and intellect is allowed to have its characteristic way of breaking up reality into pieces. Participation or empathy is the result of intellectualization. The philosopher who has no original experience is apt to indulge in it." 2)

Not only intellect restricts the spontaneity of experience, but also any authoritative concept or figure; thus Zen "does not attach any intrinsic importance to the sacred sutras or to their exegesis by the wise and learned. Personal experience is strongly acting against authority and objective revelation ..."3) In Zen God is neither denied nor insisted upon. "Zen wants absolute freedom, even from God." "4) It wants the same freedom, even, from Buddha; hence the Zen saying "Cleanse your mouth when you utter the word Buddha." 5 )

In accordance with Zen's attitude towards intellectual insight, its aim of teaching is not as in the West an everincreasing subtlety of logical thinking, but its method "consists in putting one in a dilemma, out of which one must contrive to escape not through logic indeed but through a mind of higher order." ${ }^{6)}$ Accordingly the teacher is not a teacher in the Western sense. He is a master, inasmuch as he has mastered his own mind, and hence is capable of conveying to the student, the only thing that can be conveyed: his existence. "With all that the master can do, he is helpless to make the disciple take hold of the thing, unless the latter is fully prepared for it.... The taking hold of the ultimate reality is to be done by oneself." 7)

The attitude of the Zen master to his student is bewildering to the modern Western reader who is caught in the alternative between an irrational authority which limits freedom and exploits its object, and laissez-faire - absence of any authority. Zen represents another form of authority, that of "rational authority". The master does not call the student, he wants nothing from him, not even that he becomes enlightened; the student comes of his own free will, and goes of his own free will. But inasmuch as he wants to learn from the master, the fact has to be recognized that the master is a master, that is, that the master knows what the student wants to know, and does not know yet. For the master "there is nothing to

1) Ibid, p. 41.

2) D. T.Suzuki. "Mysticism, Christian and Buddhist," World Perspectives, Vol. XII, ed. R. N. Anshen, Harper Brothers, New York, 1957, p. 105.

3) D. T.Suzuki, "Introduction to Zen," p. $34 \ldots$

4) Ibid, p.97.

5) Ibid, p. ....

6) Ibid, p. 40 .

7) D.T. Suzuki, "Zen Buddhisı", Doubleday Anchor Books, New York, 1956, p. 96. 
explain by means of words, there is nothing to be given out as a holy doctrine. Thirty blows whether you affirm or negate. Do not remain silent, nor be discursive." ${ }^{1)}$ The Zen master is characterized at the same time by the complete lack of irrational authority and by the equally strong affirmation of that undemanding authority, the seat of which is genuine experience.

Zen can not possibly be understood unless one takes into consideration the idea that the accomplishment of true insight is indissolubly connected with a change in character. Here Zen is rooted in Buddhist thinking, for which characterological transformation is a condition for salvation. Greed for possession as for anything else, self-conceit and self-glorification are to be left behind. The attitude towards the past is one of gratitude, towards the present of service and towards the future of responsibility. To live in Zen "means to treat yourself and the world in the most appreciative and reverential frame of mind," an atritude which is the basis of "secret virtue, a very characteristic feature of Zen discipline. It means not to waste natura! resources; it means to make full use, economic and moral, of everything that comes your way." 2 )

As positive aim, the ethical goal of Zen is to achieve "complete security and fearlessness", to arrive from bondage to freedom. "Zen is a matter of character and not of the intellect, which means that Zen grows out of the will as the first principle of life."

III

The assumption of the incompatibility between Zen Buddhism and psychoanalysis ${ }^{3)}$ results only from a superficial view of both. Quite to the contrary, the affinity between both seems to be much more striking. This chapter is devoted to elucidate this affinity in detail.

Let us begin with Dr. Suzuki's statements, quoted earlier, about the aim of Zen. "Zen in its essence is the art of seeing into the nature of one's own being, and it points the way from bondage to freedom.... We can say that Zen liberates all the energies properly and naturally stored in each one of us, which are in ordinary circumstances cramped and distorted so that they find no channel for activity.... It is the object of Zen, therefore, to save us from going crazy or being crippled. This is what I mean by freedom, giving free play to all the creative and benevolent impulses inherently lying in our hearts. Generally we are blind to this fact, that we are in possession of all the necessary faculties that will make us happy and loving to one another."

This description of Zen's ain could be applied without change as a description of what psychoanalysis aspires to achieve; insight into one's own nature, the achievement of freedom, happiness and love, liberation of energy, saving one from being insane or crippled. This last statement, that we are confronted with the alternative between enlightenment and insanity may sound startling, but in my opinion is born out by the observable facts. While psychiatry is concerned with the question why some people become insane, the real question is why

1) I.T. Suzuki, Introduction, p. 49.

2) D.T. Suzuki, Ibid. p. 131.

3) When I speak in this chapter of "psychoanalysis", I refer to humanistic psychoanalysis as a development from Freudian analysis, yet including those aspects of Freudian analysis which are at the root of this development. 
most people do not become insane. Considering man's position in the world, his separateness, aloneness, powerlessness and the awareness of it, one should expect that this burden is more than he can bear, and that he would, quite literally, "go to pieces" under the strain. Most people avoid this outcome by compensatory mechanisms like the overriding routine of life, conformity with the herd, the search for power, prestige and money, and dependence on idols - shared with others in religious cults -, a self-sacrificing masochistic life, narcisistic inflation, - in short, by becoming crippled. All these compensatory mechanisms can keep up sanity, provided they work up to a point. The only fundamental solution which truly overcomes potential insanity is the full, productive response to the world, which in its highest form is enlightenment.

Before we arrive at the central issue of the connection between psychoanalysis and Zen I want to begin the discussion of this connection with some more peripheral affinities:

First to be mentioned is the ethical orientation common to Zen and to psychoanalysis. A condition for achieving the aim of Zen is the overcoming of greed, be it greed for possession, or greed for glory, or any other form of greed ("coveting", in the Old Testament sense). This is exactly what the aim of psychoanalysis is. Already in his theory of the libido evolution from the oral receptive, through the oral sadistic, anal, to the genital level, Freud implicitly stated that the healthy character develops from the greedy, cruel, stingy, into an active, independent orientation. In my own terminology, which follows Freud's, I have made this value element more explicit by speaking about evolution from the receptive, through the exploitative, hoarding, marketing, to the productive orientation. ${ }^{1)}$ Whatever terminology one uses, the essential point is that in the psychoanalytic concept, greed is a pathological phenomenon; it exists where a person has not developed his active, productive capacities. Yet neither psychoanalysis nor Zen are primarily ethical systems. The aim of Zen transcends the goal of ethical behavior, and so does psychoanalysis. It might be said that both systems assume that the achievement of their aim brings with it an ethical transformation, the overcoming of greed and the capacity for love and compassion. They do not tend to making a man lead a virtuous life by the suppression of the 'evil' desire, but they expect that the evil desire will melt away and disappear under the light and warmth of enlarged consciousness. But whatever the causal connection between enlightenment and ethical transformation may be, it would be a fundamental error to believe that the goal of Zen can be separated from the aim of overcoming greed, self glorification and folly, that satori can be achieved without achieving humility and love and compassion. It would be equally a mistake to assume that the aim of psychoanalysis is achieved, unless a similar transformation in the person's character occurs. A person who has reached the productive level is not greedy, because at the same time he has overcome his grandiosity, the fiction of omniscience and omnipotence; he is humble and sees himself as he is. Both Zen and psychoanalysis aim at something transcending ethics, yet their aim can not be accomplished unless an ethical transformation takes place.

Another element common to both systems is their insistence on independence from any kind of authority. This is Freud's main reason for criticizing religion. He saw as the essence of religion the illusion of substituting the dependence on God for the original dependence

1) "Man for Himself", Rinchart and Co., Inc., New York, 1947, chapter III. 
on a helping and punishing father. In the belief in God, man, according to Freud, continues his infantile dependence, rather than to mature, and that means to rely only on his own strength. What would Freud have said to a "religion" which says: "When you have mentioned Buddha's name, wash your mouth!" What would he have said to a religion in which there is no God, no irrational authority of any kind, and whose main goal is exactly that of liberating man from all dependence, to activate him, to show him that he, and nobody else bears the responsibility for his fate?

Yet, it might be asked, does this antiauthoritarian attitude not contradict the significance of the person of the master in Zen, and of the analyst in psychoanalysis : Again, this question points to an element in which there is a profound connection between Zen and psychoanalysis. In both systems a guide is needed; one who has himself gone through the experience the person (student) under his care is to achieve. Does this mean that the student becomes dependent on the master (or psychoanalyst) and hence the master's words constitute truth for him? Undoubtedly, psychoanalysts deal with the fact of such dependence (transference) and recognize the powerful influence which it can have. But the aim of psychoanalysis is exactly to understand and eventually to dissolve this tie, and instead to bring the patient to a point where he has acquired full freedom from the analyst, because he has experienced in himself that which was unconscious and has reintegrated it into his consciousness. The Zen master - and the same can be said of the psychoanalyst knows more, and hence can have conviction in his judgment, but that does not mean at all that he imposes his judgment on the student. He has not called the student, and he does not prevent him from leaving him. If the student voluntarily comes to him and wants his guidance in walking the steep path to enlightenment, the master is willing to guide him, but only under one condition: that the student understands that, much as the master wants to help him, the student must look after himself. None of us can save anybody else's soul. One can only save oneself. All the master can do is to play the role of a midwife, of the guide in the mountains. As one master said, "I really have nothing to impart to you and if I tried to do so, you might have occasion to make me an object of ridicule. Besides, whatever I can tell you is my own, and can never be yours."

A very striking and concrete illustration of the Zen master's attitude is to be found in Herrigel's book on the Art of Archery. ${ }^{1)}$ The Zen master insists upon his rational authority, that is to say, that he knows better how to achieve the art of archery, and therefore must insist on a certain way of learning it, but he does not want any irrational authority, any power over the student, or the continued dependence of the student on the master. On the contrary, once the student has become a master himself, he goes his own way and all the master expects from him is a picture from time to time which would show him how the student is doing. It might be said that the Zen master loves his students. His love is one of realism and maturity, of making every effort to help the student in achieving his aim, and yet of knowing that nothing the master does can solve the problem for the student, can achieve the aim for him. This love of the Zen master is non-sentimental, realistic love, one which accepts the reality of human fate in which none of us can save the other, and yet in which we must never cease to make every effort to give help so that another can save himself. Any love which does not

1) E. Herrigel "Zen in the Art of Archery", Pantheon Books, New York, 1953. 
know this limitation, and claims to be able to "save" another soul, is one which has not rid it self of grandiosity and ambition.

It hardly needs any further proof that what has been said about the Zen Master in principle holds true (or should hold true) for the psychoanalyst. Freud thought that this independence of the patient from the analyst could best be established by the mirror-like, impersonal attitude of the analyst. But also those analysts like Ferenczi, Sullivan, myself and others, who stress the need for relatedness between analyst and patient as a condition for understanding, would entirely agree that this relatedness must be free from all sentimentality, unrealistic distortions and especially, from any - even the most subtle and indirect - interference of the analyst in the life, aims and ideas of the patient. Even the aim that the patient gets well should not have any particular emotional appeal to the analyst. If the patient wants to get well and to change - that is fine, and the analyst is willing to help him. If his resistance to change is too great, this is not the analyst's responsibility. All his responsibility lies in lending the best of his knowledge and effort of giving himself to him in search of the aim the patient seeks him out for.

Related to the attitude of the analyst is another affinity between Zen Buddhism and Psychoanalysis. The "teaching" method of $Z_{e n}$ is to drive the student into a corner as it were. The Koan makes it impossible for the student to seek refuge in conventional thought; the Koan is like a barrier which makes further flight impossible. The analyst does - or should do - something similar. He must avoid the error of feeding the patient with interpretations and explanations which only prevent the patient from making the jump from thinking into experiencing. On the contrary, he must take away one rationalization after another, one crutch after another, until the patient cannot escape any longer and breaks through the fictions which fill his mind, and experiences reality - that is, becomes conscious of something he was not conscious of before. This process often produces a good deal of anxiety, and sometimes the anxiety would prevent the break-through, were it not for the reassuring presence of the analyst. But this reassurance is one of 'being there' - and not one of words which tend to inhibit the patient from experiencing what only he alone can experience.

The more psychoanalysis developed, the clearer it became that effective insight was not a thought, but an experience of "seeing" something as new-and yet as if one had always known it. The authentic psychoanalytic insight is sudden; it arrives without being forced or even being premeditated. It appears not in our brain but, to use a Japanese image, in our belly. It cannot adequately formulated in words, and it eludes one if one tries to do so; yet it is real, and conscious, and it leaves the person who experiences it a changed person. The connection between the psychoanalytic attitude toward conscious thought and psychoanalytic "insight" with the corresponding Zen attitude and Zen-enlightenment hardly needs any further comment. The critical evaluation of intellect and thought constitutes one of the essential points in Zen. More radically than any other system, Zen has recognized that intellect constitutes the danger of becoming a substitute for experience. Zen is a living protest against the assumption that the answer to the problem of human existence can ever be found in a thought. It can be found only in an experience which can not be expressed in thought. Psychoanalysis follows in the same path. Its whole method which aims at insight, aims at an insight which 
is not at all of an intellectual nature, but in its immediacy, totality and suddenness, close to Zen enlightenment.

Our discussion thus far has dealt with tangential points of similarity or affinity between Zen Buddhism and psychoanalysis. But no such comparison can be satisfactory unless it deals squarely with the main issue of Zen, which is enlightenment, and the main issue of psychoanalysis, which is the overcoming of repressedness, the transformation of the unconscious into consciousness.

Let us sum up what has been said about this problem as far as psychoanalysis is concerned. The aim of psychoanalysis is to make the unconscious conscious. However, to speak of "the" conscious and "the" unconscious, means to take words for realities. We must stick to the fact that conscious and unconscious refer to functions, not to places or contents. Properly speaking, then, we can talk only of a state of greater or lesser repressedness, that is, a state in which only those experiences are permitted to come to awareness which can penetrate through the social filter of language, logic and content. To the degree to which I can rid myself of this filter and can experience myself as the universal man, that is, to the degree to which repressedness diminishes, I am in touch with the deepest sources within myself, and that means within all of humanity, all of the cosmos. If all repressedness has been lifted, there is no more unconscious as against conscious; there is direct, immediate experience; inasmuch as I am not a stranger to myself, no one and nothing is a stranger to me. There is another aspect to the process of increasing consciousness. To the degree to which part of me is alienated from me, and my "unconscious" is separated from my conscious (that is I, the whole man, am separated from the I - the social man), my grasp of the world is falsified in several ways. First, in the way of parataxic distortions (transference); I experience the other person not with nuy total self, but, with my split, childish self, and thus another person is experienced as a significant person of one's childhood, and not as the person he really is.

Furthermore, man in the state of repressedness experiences the world with a false consciousness. He does not see what exists, but he puts his thought image into things, and sees them in the light of his thought images and fantasies, but he does not see reality. It is the thought image, the distorting veil, that createshis passions, his anxieties. Eventually, the repressed man, instead of experiencing things and persons, experiences by cerebration. He is under the illusion of being in touch with the world - while he is only in touch with words. Parataxic distortion, false consciousness and cerebration are not strictly separate ways of unreality; they are, rather, different and yet overlapping aspects of the same phenomenon of unreality which exists as long as the universal man is separated from the social man. We only describe the same phenomenon in a different way by saying that the person who lives in the state of repressedness is the alienated person. He projects his own feelings and ideas on objects, and then does not experience himself as the subject of his feelings, but is ruled by the objects which are charges with his feelings.

The opposite of the alienated, distorted, parataxic, false, cerebrated experience, is the immediate, direct, total grasp of the world which we see in the infant and child before the power of education changes this form of experience. For the new-born infant there is as yet no separation between the me and the not me. This separation gradually takes place, and the final 
achievement is expressed by the fact that the child can say "I". But still the child's grasp of the world remains relatively immediate and direct. When the child plays with a ball, it really sees the ball moving, it is fully in this experience. and that is why it is an experience which can be repeated without end, and with a neverceasing joy. The adult also believes that he sees the ball rolling. That is of course true, inasmuch as he sees that the object $=$ ball is rolling on the object $=$ floor. But he does not really see the rolling. He thinks the rolling ball on the surface. When he says 'the ball rolls', he actually confirms only a) his knowledge that the round object over there is called a ball and b) his knowledge that round objects roll on a smooth surface when given a push. His eyes operate with the end of proving his knowledge, and thus making him secure in the world.

The state of non-repressedness is a state in which one acquires again the immediate, undistorted grasp of reality, the sinpleness and spontaneity of the child - and yet after having gone through the process of alienation, of development of one's intellect, non-repressedness is return to innocence on a higher level; this return to innocence is possible only after one has lost one's innocence.

This whole idea has found a clear expression in the Old Testament, in the story of the Fall, and in the prophetic concept of Messianism. Man, in the biblical story, finds himself in a state of undifferentiated unity in the Garden of Eden. There is no consciousness, no differentiation, no choice, no freedom, no sin. He is part of nature, and he is not aware of any distance between hinself and nature. This state of primordial, pre-individual unity is disrupted by the first act of choice, which is at the same time the first act of disobedience, and of freedom. The act brings about the emergence of consciousness. Man is aware of himself as he, of his separateness from Eve :- the woman, and from nature, animals and the earth. When he experiences this separateness he feels ashamed - as we all still feel ashamed (though unconsciously) when we experience the separateness from our fellowman. He leaves the Garden of Eden, and this is the beginning of human history. He can not return to the original state of harmony; yet he can strive for a new state of harmony by developing his reason, his objectivity, his conscience and his love fully, so that, as the prophets express it, the 'earth is full of the knowledge of God as the ocean is full of water.' Histroy, in the Messianic concept, is the place in which this development from pre-individual, pre-conscious harmony to a new harmony occurs, a harmony based on the completion and perfection of the development of reason. This new state of harmony is called the Messianic time in which the conflict between man and nature, man and man, has disappeared, in which the desert becomes a fruitful valley, in which the lamb and the wolf rest side by side, and in which swords are transformed into ploughshares. The Messianic time is the time of the Garden of Eden, and yet it is its opposite. It is oneness, immediacy, entirety, but of the fully developed man who has become a child again, yet has outgrown being a child.

The same idea is expressed in the New Testament. "Truly, I say to you, whosoever does not receive the Kingdom of God like a child shall not enter it." 1 ) The meaning is clear: we have to become children again, to experience the unalienated, creative grasp of the world; but in becoming children again, we are at the same time not children, but fully developed

1) Luke 18. 17 . 
adults. Then, indeed, we have the experience which the New Testament describes like this: "For now we see in a mirror dimly, but then face to face. Now I know in part; then I shall understand fully even as I have been fully understood."1)

To "become conscious of the unconscious" means to overcome repressedness and alienation from myself, and hence from the stranger. It means to wake up, to shed illusions, fictions and lies, to see reality as it is. The man who wakes up is the liberated man, the man whose freedom cannot be restricted either by others or by himself. The process of becoming aware of that which one was not aware of, constitutes the inner revolution of man. It is the true awakening which is at the root of both creative intellectual thought and intuitive immediate grasp. To lie is possible only in a state of alienation, where reality is not experienced except as a thought. In the state of being open to reality which exists in awakeness, the lie is impossible because it would melt under the strength of experiencing fully. In the last analysis, to make the unconscious conscious means to live in truth. Reality has ceased to be alienated, I am open to it, hence my responses to it are "true".

This aim of the immediate, full grasp of the world is the aim of Zen. Since Suzuki has written a chapter on the unconscious in this book, I can refer to his discussion, and thus try to clarify further the connection between the psychoanalytic and the Zen concept.

First of all I should like to point again to the terminological difficulty which, I believe, unnecessarily complicates matters; the use of the conscious and the unconscious, instead of the functional term of greater or lesser awareness of experience in the total man. I believe, if we free our discussion from these terminological obstacles, Suzuki's discussion tends to confirm my suggestion that the true meaning of making the unconscious conscious expresses essentially the same goal as that of enlightenment.

"The Zen approach is to enter right into the object itself as it were, from the inside." 2) This immediate grasp of reality "may also be called conative or creative." 3) Suzuki then speaks of this source of creativity as of "Zen's unconscious" and continues to say that "the unconscious is something to feel, not in its ordinary sense, but in what I would call the most primary and fundamental sense." 4) The formulation speaks here of the unconscious as of a realm within the personality and transcending it, and as Suzuki goes on to say "the feeling of the unconscious is ... basic and primary" 5) - Translating this into functional terms I would not speak of feeling "the" unconscious, but rather of being aware of a deeper and not conventionalized area of experience, or to put it differently, lessening the degree of repressedness, and thus reducing the parataxic distortion, image projections and cerebration of reality. When Suzuki speaks of the Zen-man as being "in direct communication with the unconscious", 6) I would prefer the formulation: being aware of his own reality, and the reality of the world in its full depth and without veils. Suzuki uses a little later the same functional language when he states: "In fact, it (the unconscious) is on the contrary the most intricate thing to us and it is just because of this intricacy that it is difficult to take hold of in the same way as the eye can not see itself. To become, therefore, conscious of the unconscious requires a special training on the part of the conscious." 7) Here Suzuki chooses a formulation which would

1) Corinth I, 13; 11.

3) Ibid. p, 3 .

2) D. T. Suzuki's paper, p. 2.4 4) Ibid, p. 6.

5) Ibid, p. 6.

7) Ibid, p. 11 (My italics, E. F.)

6) D. T. Suzuki's paper, p. 9. 
be exactly the one chosen from the psychoanalytic standpoint: the aim is to become conscious of the unconscious, and in order to achieve this aim a special training on the part of consciousness is necessary. Does this imply that both Zen and psychoanalysis have the same aim, and that they differ only in the method of the training of the consciousness they have developed?

Before we return to this point, I should like to discuss a few other points which need to be clarified.

Dr. Suzuki, in his discussion, refers to the same problem which I mentioned in the discussion of the psychoanalytic concept above, that of knowledge vs. the state of innocence. What is called in biblical terms the loss of innocence, through the acquisition of knowledge, is called in Zen and in Buddhism generally "the 'affective contamination (Klesha)' or the interference of the conscious mind predominated by intellection (vijnanna)." The term intellection raises a very important problem. Is intellection the same as consciousness? In this case, making the unconscious conscious would imply to further intellection and indeed lead to exactly the opposite aim of that which is Zen's. If this were so, then indeed the aim of psychoanalysis and of Zen would be diametrically opposed, the one striving for more intellection, the other striving for the overcoming of intellection.

It must be admitted that Freud in the earlier years of his work, when he still believed that the proper information given the patient by the psychoanalyst was enough to cure him, had a concept of intellection as the goal of psychoanalysis; it must be admitted further that many analysts in practice have still not emerged from this concept of intellection, and that Freud never expressed himself with full clarity on the difference between intellection and the affective, total experience which occurs in genuine "working through". But this new and not intellectual insight is the aim of psychoanalysis. As I stated before, to be aware of my breathing does not mean to think about my breathing. To be aware of the movement of my hand does not mean to think about it. On the contrary, once I think about my breathing, or the movement of my hand, I am not any more aware of my breathing or of the movement of my hand. The same holds true of my awareness of a flower, a person, of my experience of joy, love or peace. It is characteristic of all true insight in psychoanalysis that it can not be formulated in thought, while it is characteristic of all had analysis that "insight" is formulated in complicated theories which have nothing to do with immediate experience. The immediate grasp of the world in the infant is one before consciousness, objectivity, sense of reality as separate from self are fully developed. In this state "the unconscious is an instinctive one, it does not go beyond that of animals and infants. It can not be that of the mature man." 2 ) During the emergence from primitive, preconscious ${ }^{3)}$ unconsciousness, the world is experienced on the basis of the split between subject and object, of separation between the universal man and the social man, between unconscious and consciousness. To the degree, however, to which consciousness is trained to open itself, to loosen the threefold filter, the discrepancy between consciousness and unconsciousness disappears. When it has fully disappeared there is direct, unreflected conscious experience, precisely the kind of experience which exists with-

1) Ibid, p. 13.

2) The term pre-conscious is of course used here in a different sense from Freud's use of it. 
out intellection and reflection. This knowledge is what Spinoza called the highest form of knowledge, intuition; the knowledge which Suzuki describes as the approach which "is to enter right into the object itself and see it as it were from the inside;" it is the conative or creative way of seeing reality. In this experience of the immediate, unreflected grasp, man becomes the "creative artist of life" which we all are and yet have forgotten that we are. "To such (creative artists of life) his every deed expresses originality, creativity, his living personality. There is no conventionality, no conformity, no inhibiting motivation .... He has no self, encased in his fragmentary, limited, restrained egocentric existence. He is gone out of this prison." 1 )

The "mature man" if he has cleansed himself of "affective contamination" and the interference of intellection, can realize a life of freedom and spontaneity where such disturbing feeling of fear, anxiety or insecurity have no room to assail him." 2) What Suzuki says here of the liberating function of this achievement is, indeed what from the psychoanalytic standpoint would be said of the expected effect of full insight.

There remains a question of terminology which I want to mention only briefly since, like all terminological questions, it is not of great importance. I mentioned before that Suzuki speaks of the training of consciousness; but in other places he speaks of the "trained unconsciousness" in which all the conscious experiences he has gone through since infancy are incorporated as constituting his whole being". 3) One might find a contradiction in the way of speaking one time of the "trained consciousness" and another time of the "trained unconsciousness." But actually I do not believe that we deal here with a contradiction at all. In the process of making the unconscious conscious, of arriving at the full and hence unreflected reality of experience, both the conscious and the unconscious must be trained. The conscious must be trained to loosen its reliance on the conventional filter, and the unconsciousness must be trained to emerge from its secret, separate existence, into the light. But in reality, speaking of the training of consciousness and unconsciousness means using metaphors. Neither the unconscious nor the conscious need to be trained (since there is neither a conscious nor an unconscious), but man must be trained to drop his repressedness and to experience reality fully, clearly, in all awareness, and yet without intellectual reflection, except where intellectual reflection is wanted or necessary, as in science and in practical occupations.

Suzuki suggests calling this unconsciousness the Cosmic Unconscious. There is, of course, no valid argument against this terminology, provided it is explained as clearly as it is done in Suzuki's text. Nevertheless, I would prefer to use the term "Cosmic Consciousness" which Bucke used to denote a new, emerging form of consciousness. 4 ) I would prefer this term, because if, and to the degree to which the unconscious becomes conscious, it ceases to be unconscious (always keeping in mind that it does not become reflective intellection). The cosmic unconsciousness is the unconscious only as long as we are separated from it, that is, as long as we are unconscious of reality. To the degree to which we awaken and are in touch with reality, there is nothing we are unconscious of. it must be added that by using the term Cosmic Consciousness rather than conscious reference is made to the function
1) Ibid, p. $8 / 9$.
2) Ibid, p. 14.
3) Ibid, p. 13.
4) In the following page. 
of awareness rather than to a place within the personality.

Where does this whole discussion lead us with regard to the relationship between Zen Buddhism and psychoanalysis?

The aim of Zen is enlightenment; the immediate, unreflected grasp of reality, without affective contamination and intellectualization, the realization of the relation of myself to the Universe. This new experience is a repetition of the pre-intellectual, immediate grasp of the child, but on a new level, that of the full development of man's reason, objectivity, individuality. While the child's experience, that of immediacy and oneness lies before the experience of alienation, and the subject-object split, the enlightenment experience lies after it.

The aim of psychoanalysis, as formulated already by Freud, it that of making the unconscious conscious, of replacing Id by Ego. To be sure, the content of the unconscious to be discovered was limited to a small sector of the personality, to those instinctual drives which were alive in early childhood, but which were subject to amnesia; to lift them out of the state of repression was the aim of the analytic technique. Furthermore, the sector to be uncovered, quite aside from Freud's theoretical premises, was determined by the therapeutic need to cure a particular symptom. There was no interest in recovering unconsciousness outside of the sector related to the symptom formation. Slowly the introduction of the concept of the death instinct and eros, and the development of the Ego aspects in recent years brought about a certain broadening of the Freudian concepts of the contacts of the unconscious. The non-Freudian schools widened the sector of the unconscious to be uncovered much further; most radically Jung, but also Adler, Rank and the other more recent so-called neo-Freudian authors. But, in spite of such a widening, the extent of the sector to be uncovered remained determined by the therapeutic aim of curing this or that symptom, or this or that neurotic character trait. It did not encompass the whole person.

However, if one follows the original aim of Freud, that of making the unconscious conscious, to its last consequences, one must free it from the limitaions which followed from Freud's own instinctual orientation, and from the immediate task of curing sickness. If one pursues the aim of the full recovery of the unconscious - then this task is not restricted to the instincts, nor to other limited sectors of experience, but to the total experience of the total man; then the aim becomes that of overcoming alienation, and of the subject-object split in perceiving the world; then the uncovering of the unconscious means the overcoming of affective contamination and cerebration; it means the disappearance of the state of repressedness, the abolition of the split within myself between the universal man and the social man; it

4) Richard R. Bucke, Cosmic Consciousness, A Study in the Evolution of the Human Mind, Innes \& Sons, 1901, republished by Dutton Co., New York, 1923. 17th Edition 1954. It should be mentioned, though only in passing, that Bucke's book is perhaps the book most germain to the topic of this article. Bucke, a psychiatrist of great knowledge and experience, a socialist with a profound belief in the necessity and possibility of a socialist society which "will abolish individual ownership and rid the earth at once of two immense evils - riches and poverty", develops in this book a hypothesis, of the evolution of human consciousness. According to this hypothesis, man has progressed from animal 'simple consciousness' to human self-consciousness, and is now on the threshold of developing Cosmic Consciousness, a revolutionary event which has already occurred in a number of extraordinary personalities in the last two thousand years. What Bucke describes as cosmic consciousness is, in my opinion, precisely the experience which is called "satori" in Zen Buddhism. 
means the disappearance of the polarity of conscious vs. unconscious; it means arriving at the state of the immediate grasp of reality, without distortion and without interference by intellectual reflection; it means the overcoming of the craving to hold on to the ego, to worship it; it means to give up the illusion of an indestructible separate ego, which is to be preserved, enlarged, as the Egyptian Pharaos hoped to preserve themselves as mummies for eternityTo be conscious of the unconscious means to be open, responding, to have nothing and to be.

This aim of the full recovery of unconsciousness by consciousness is quite obviously much more radical than the psychoanalytic aim as it is generally practiced. The reasons for this are easy to see. To achieve this total aim requires an effort far beyond the effort most persons in the West are willing to make. But quite aside from this question of effort, even the visualization of this aim is possible only under certain conditions. First of all, this radical aim can be envisaged only from the point of view of a certain philosophical position. There is no need to describe this position in detail. Suffice it to say that it is one in which not the negative aim of the absence of sickness, but the positive one of the presence of well-being is aimed at, and that well-being is conceived in terms of full union, the immediate and uncontaminated grasp of the world. This aim could not be better described than has been done by Suzuki in terms of "the art of living". One must keep in mind that any such concept as the art of living grows from the soil of a spiritual humanistic orientation, as it underlies the teaching of Buddha, of the prophets, of Jesus, of Master Eckhardt, or of men such as Blake, Walt Whitman or Bucke. Unless it is seen in this context, the concept of "the art of living" loses all that is specific, and deteriorates into a concept that goes today under the name of "happiness". It must also not be forgotten that this orientation includes an ethical aim while Zen transcends ethics, it includes the basic ethical aims of Buddhism which are essentially the same as those of all humanistic teaching. The achievement of the aim of Zen, as Suzuki has made very clear in the lectures in this book, implies the overcoming of greed in all forms, whether it is the greed for possession, for fame, or the greed for affection; it implies overcoming narcisistic self-glorification and the illusion of omnipotence. It implies, furthermore, the overcoming of the desire to submit to an authority who solves one's own problem of existence. The person who only wants to use the discovery of the unconscious to be cured of sickness will, of course, not even attempt to achieve the radical ain which lies in the overcoming of repressedness.

But it would be a mistake to believe that the radical aim of the overcoming of repressedness has no connection with a therapeutic aim. Just as one has recognized that the cure of a symptom and the prevention of future symptom formations is not possible without the analysis and change of the character, one must also recognize that the change of this or that neurotic character trait is not possible without pursuing the more radical aim of a complete transformation of the person. It may very well be that the relatively disappointing results of character analysis (which have never been expressed more honestly than by Freud in his "Analysis, Terminable or Interminable?") are due precisely to the fact that the aims for the cure of the neurotic character were not radical enough; that wellbeing, freedom from anxiety and insecurity, can be achieved only if the limited, practical aim is transcended, that is, if one realizes that the limited, therapeutic aim cannot be achieved as long as it remains limited and does not become part of a wider, humanistic frame of reference. Perhaps the limited aim can be achiev- 
.ed with more limited and less time-consuming methods, while the time and energy consumed in the long analytic process are used fruitfully only for the radical aim of 'transformation' rather than the narrow one of 'reform'. This proposition might be strengthened by referring to a statement made above. Man, as long as he has not reached the creative relatedness of which satori is the fullest achievement, at best compensates for the inherent potential depression - by routine, idolatry, destructiveness, greed for property or fame, ete. when any - of these compensations break down, his sanity is threatened. The cure of the potential insanity lies only in the change in attitude from split and alienation to waking up, to the creative, immediate grasp of and response to the world. If psychoanalysis can help in this way, it can help to achieve true mental health; if it can not, it will only help to improve coinpensatory mechanisms. To put it still differently: somebody may be "cured" of a symptom, but he can not be "cured" of a character neurosis. Man is not a thing, ${ }^{11}$ man is not a case, and the analyst does not cure anybody by treating him as an object. He can only help him to wake up in a process in which the analyst is engaged with the "patient" in the process of understanding each other, and that means, of experiencing their oneness.

In stating all this, however, we must be prepared to be confronted with an objection. If, as I said above, the achievement of the full consciousness of the unconscious is as radical an aim as enlightenment, does it make any sense to discuss this radical aim as something which has any general application? It it not purely speculative to raise the question seriously that only this radical aim can justify the hopes of psychoanalytic therapy?

If there were only the alternative between full enlightenment and nothing, then indeed this objection would be valid. But this is not so. In Zen there are many stages of enlightenment, of which satori is the ultimate and decisive step. But, as far as I understand, not little is thought of experiences which are steps in the direction of satori, alchough satori may never be reached. Dr. Suzuki once illustrated this point in the following way: if one candle is brought into an absolutely dark room, the darkness has disappeared, and there is light. But if ten or a hundred or a thousand candles are added, the room will become brighter and brighter. Yet, the decisive change was brought about by the first candle which penetrated the darkness. ${ }^{2}$ )

What happens in the analytic process? A person senses for the first time that he is vain, that he is frightened, that he hates, while consciously he had believed himself to be modest, brave and loving. The new insight may hurt him, but it opens his prison; it permits him to stop projecting on others what he represses in himself. He proceeds; he experiences the infant, the child, the adolescent, the criminal, the insane, the saint, the artist, the male and the female within himself; he gets more deeply in touch with humanity, with the universal man, he represses less, is freer, has less need to project, to cerebrate; then he may experience how for the first time he sees colors, how he sees a ball roll, how his ears are suddenly fully opened to music, when up to now he only listened to it; in sensing his oneness with others, he may have a first glimpse of the illusion that his separate individual ego is something to hold onto,

1) cf. my paper: "The Dangers and Limitations of Psychology" in Religion and Culture, Easays in Honor of Paul Tillich, ed. by W. Leibrecht, Harper and Brothers, New York, 1959, p. 31 ff. .

2) In a personal communication, as I remember it. 
to cultivate, to save; he will experience the futility of seeking, the answer to life by having himself - rather than by being himself. All these are experiences with no intellectual content; sudden, unexpected, yet after the experience the person feels freer, stronger, less anxious than he ever felt before.

So far we have spoken about the aims, and I have proposed that if one carries Freud's principle of the transformation of the unconsciousness into consciousness to its ultinate consequences, one approaches at the concept of enlightenment. But if we speak of methods to achieve this aim then, indeed, psychoanalysis and Zen represent two entirely different methods. The method of Zen is, one might say, that of a frontal attack on the alienated way of perception by means of the 'sitting', the Koan and the authority of the master. Of course, all this is not a 'technique' which can be isolated from the promise of Buddhist thinking, of the behavior and ethical values which are embodied in the master, and in the atmosphere of the monastery. It must also not be ignored that it is not a 'five hours a week' concern, and that by the very fact of coming for instruction in Zen a most important decision has been made, a decision which is an important part of what goes on afterwards.

The psychoanalytic method is entirely different from the Zen method. It trains consciousness to get hold of the unconscious in a different way. It directs attention to that perception which is distorted, it leads to a recognition of the fiction within oneself, it widens the range of human experience by lifting repressedness. The analytic method is psychologicalempirical. It proceeds by uncovering illusions within oneself about the world step by step, so that parataxic distortions, and alienated intellectualizations diminish; by becoming less of a stranger to himself, the world becomes less estranged to the person who goes through this process; because he has opened up communication with the universe within himself, he has opened up communication with the universe. False consciousness disappears, and with it, the polarity conscious-unconscious. A new realism dawns in which 'the mountains are mountains again.' The psychoanalytic method is of course only a method, a preparation; but so is the Zen method. By the very nature of a method it never guarantees the achievement of the goal. The factors which permit this achievement are deeply rooted in the personality, and for all practical purposes we know little of them.

I have suggested that the method of uncovering the unconscious if carried to its ultimate consequences may be a step toward enlightenment, provided it is taken within the philosophical context which is most radically and realistically expressed in Zen. But only a great deal of further experience in applying this method can show how far it can lead. At this moment the view expressed here implies only a possibility and thus has the character of a hypothesis which is to be tested.

But what can be said with more certainty is that the knowledge of, and a concern with Zen can have a most fertile and clarifying influence on the theory and technique of psychoanalysis. Zen, different as it is in its method from psychoanalysis, can sharpen the focus, throw a light on the nature of insight, and heighten the sense of what it is to see, what it is to be creative, what it is to overcome the affective contaminations and false intellectualizations which are the necessary results of experience based on the subject-object split.

In its very radicalism with respect to intellectualization, authority, and the delusion of 
the ego, in its emphasis on the aim of wellbeing, Zen thought will deepen and widen the horizon of the psychoanalyst, and help him on the path where a radical concept of making the unconscious conscious may lead to the goal of full awakening, of enlightenment.

If further speculation of the relation between $Z$ en and psychoanalysis is permissible, one might think of the possibility that psychoanalysis may be significant to the student of Zen. I can visualize that it can help to avoid the danger of a false enlightenment - (which is, of course, no enlightenment), one which is purely subjective, based on psychotic or hysterical phenomena, or on a self-induced state of trance. Analytic clarification might help the Zen student to avoid illusions, the absence of which is the very condition of enlightenment.

Whatever the use is that Zen may make of psychoanalysis, from the standpoint of a Western psychoanalyst I express my gratitude for this precious gift of the East, and to Dr. Suzuki as the one who has succeeded in expressing it in such a way that none of its essence becomes lost in the attempt to translate Eastern into Western thinking, and yet so that the Westerner, if he takes the trouble, can arrive at an understanding of Zen, as far as it can be arrived at before the goal is reached. How could such understanding be possible, were it not for the fact that "Buddha nature is in all of us", that man, the universe, existence, are universal categories, and that the immediate grasp of reality, waking up, enlightenment, are universal experiences.

MS. received III 14, 59.

Erich Fromm (1900 - ） Ph. D. 1922, University of Heidelberg. Fellow, 1942 -William Alanson White Institute of Psychoanalysis; Professor, 1952 - National University of Mexico; Professor, 1958 - Michigan State University. 